\title{
Development of a management model of support services in biotechnology companies
}

\author{
Desarrollo de un modelo de gestión en servicios de apoyo en empresa biotecnológica
}

\author{
Daimée Padilla-Aguiar (1D), José Antonio Acevedo-Suárez (D) ${ }^{2}$, Ana Julia Urquiaga-Rodríguez (D) ${ }^{3}$, Ana \\ Julia Acevedo-Urquiaga (1D ${ }^{4}$, Neyfe Sablón-Cossío (iD ${ }^{*}$ \\ ${ }^{1}$ Aseguramiento de la producción, Centro de Inmunología Molecular. Calle 15 esquina 216 s/n. C. P. 11600. La Habana, \\ Cuba. \\ ${ }^{2}$ Laboratorio de Logística y Gestión de la Producción LOGESPRO, Universidad Tecnológica de La Habana "José Antonio \\ Echeverría". Calle 114 \# 11901 / Ciclovía y Rotonda. C. P. 19390. La Habana, Cuba. \\ ${ }^{3}$ Ingeniería Industrial, Universidad Tecnológica de La Habana "José Antonio Echeverría". Calle 114 \# 11901 Ciclovía y \\ Rotonda. C. P. 19390. La Habana, Cuba. \\ ${ }^{4}$ Ingeniería Industrial, Fundación Universitaria San Mateo. Transversal 17 \# 25-25. C.P. 111921. Bogotá, Colombia. \\ ${ }^{5}$ Instituto de Posgrado, Grupo de Producción y Servicios, Universidad Técnica de Manabí. Avenida Urbina y Portoviejo. C. \\ P. 130105. Manabí, Ecuador.
}

\section{CITE THIS ARTICLE AS:}

D. Padilla, J. A. Acevedo, A. J. Urquiaga, A. J. Acevedo and N. Sablón. "Development of a management model of support services in biotechnology companies", Revista Facultad de Ingeniería Universidad de Antioquia, no. 106, pp. 25-35, Jan-Mar 2023. [Online].

Available: https :

//www.doi.org/10.17533/

udea.redin. 20220268

\section{ARTICLE INF0:}

Received: April 28, 2021

Accepted: February 20, 2022

Available online: February 23, 2022

\section{KEYWORDS:}

Service model; service management; management model; customer satisfaction; process assurance model

Modero de servicio; gestión de servicios; modelo de gestión; satisfacción del cliente; modelo de aseguramiento de procesos

\begin{abstract}
Support services are very significant for the correct performance of key processes; in the case of the biotechnology industry, this type of services is not frequently analyzed in their excellence performance. The purpose of this work is to suggest a model for the development of Support Services Management, which highlights the impacts over the level of customer satisfaction with the logistics system of biotechnology companies in the specific conditions of Cuba; however it can be applied to other contexts. For this, the basic elements of the management and service models are clarified as a theoretical basis for this research. As a methodology, experimentation and case studies are chosen, including the development of a production support service in the biotechnology industry. The level of customer satisfaction and the costs incurred are determined; In addition, the influence of the level of integration of support services on the results of the model is taken into account. The document provides the results of the model and its application in the biotechnology industry in Cuba, through a procedure designed for its implementation. This research satisfies the identified need to improve internal customer satisfaction based on quality and timely delivery of resources. At the same time, the costs of the logistics system are reduced or maintained, because the main cost must be in the key services.
\end{abstract}

RESUMEN: Los servicios de apoyo son de gran importancia para el correcto desempeño de los procesos claves, en el caso de la industria biotecnológica, no a menudo analizados en su desempeño de excelencia. Este trabajo tiene como propósito proponer un modelo de desarrollo de la Gestión de Servicios de Apoyo, que resalte cómo este impacta en el nivel de satisfacción del cliente del sistema logístico de las empresas biotecnológicas en las condiciones de Cuba, sin embargo, este puede ser aplicado en otros contextos. Para ello se esclarecen elementos básicos en los modelos de gestión y servicio como base teórica de la investigación. Como metodología se emplea la experimentación y el estudio de casos; se presenta un servicio de apoyo a la producción en la industria biotecnológica. Se determina el nivel de satisfacción del cliente y costos incurridos; además, se tiene en cuenta la influencia del nivel de integración de los servicios de apoyo en los resultados del modelo. Este documento brinda los resultados del modelo y su aplicación en una industria biotecnológica de Cuba, mediante un procedimiento de implementación.




Esta investigación satisface la necesidad identificada de mejorar la satisfacción de los clientes internos a partir de la entrega con calidad y en tiempo de los recursos; al mismo tiempo que se reducen o mantiene los costos del sistema logístico, pues los principales costos deben estar en los servicios clave.

\section{Introduction}

Innovation and high technology companies such as those in the biotech sector, constitute not only a dynamic field of research and generation of new knowledge, but also an economic engine that allows the creation of companies based on innovation [1].

Cuban biotechnology has advanced towards a working system focused on business management processes and techniques that thoroughly permeate every area of the organizations in this sector [2]. However, development and improvement are centered on these companies' key processes, leaving support services behind.

At the international level, specialized companies are contracted to provide conventional services; however, in the Cuban context, most of these services are contracted internally. Half of the eight biotechnology companies of the Cuban Scientific Facilities Cluster manage their own support services, i.e., none of them has outsourced services and the remaining half use mixed systems. Within the mixed systems, only $25 \%$ of services (8) are outsourced to Transmetro, SERVIGEN and cooperatives.

The country is in no condition to undertake the outsourcing of all support services. Studies on the situation of logistics and value networks in Cuban companies [3-7] reveal the following deficiencies: conceptual and managerial aspects are the main causes of delays in the performance of the logistic system of the companies under study; postgraduate training in this area and the application of the content of logistics to management are insufficient and result in inefficient use of available resources; the companies included in the Value Network Model are evaluated as medium level. The elements that were identified as being in the low-medium range of evaluation include: integration management, customer service, demand management, innovation management and staff, product or service development; another weakness is that the customer is not always seen as the main link of the entire value chain, from the demand to the delivery of the service.

The situation of logistics in recent years has not changed significantly. Companies are waiting for an external result; that is to say, they are waiting for the environment to change, but management must be undertaken on the basis of the organizations' internal conditions. Under the new forms of business management, it has become a challenge to offer good-quality conventional services that are well designed and aligned, and satisfy customers' needs based on the requirements and characteristics of logistic systems.

In the case of the Molecular Immunology Center (CIM, by its Spanish acronym), which is a biotechnological institution, the examination of its support processes [8-11] shows that the general evaluation of the application of the Logistics Reference Model was low, with a grade of 2.45 points; there is insufficient innovation in support processes of the supply chain and administrative management; financing-related deficiencies were detected in the management of engineering systems and the replacement of obsolete equipment; and the performance of processes and logistics has been low with respect to the completion of authentication procedures abroad and the calibration of standards and equipment. Likewise, there have been problems with the purchase of supplies for research, and the availability of funds for research, development and production.

For the development of the closed cycle, it is necessary to create and improve support services with a high level of knowledge integration, which will allow taking logistics to higher levels, in order to meet the demands of the key processes of the CIM. In this organization, support services for research and production are being delivered in different areas, while conventional support services are concentrated in SERVICIM.

Since 2000, there has been research work on the management system of CIM's support services [12]; in 2012, integrated management was proposed as an alternative for improvement [13] and in 2014, the integration level of the management system was measured for the first time [14].

As a result of this last analysis, it was determined that problems are caused by the low level of development and integration of the management, information and planning systems of support services, making it impossible to increase their effectiveness within biotechnology companies. Therefore, the following question may be raised: How can the integration of support services be achieved to condition an effective logistic system in a biotechnology company?

The objective of this research is to develop a Support Services Management Model (MOGESA, by its Spanish acronym), to raise the level of customer satisfaction with the logistic system in a biotechnology company. 
The research method used is based on experimentation and case studies; the authors have been working on these topics from 2000 until the present. The techniques and tools applied included satisfaction surveys [15], experience sharing, brainstorming, inspection guides, consultation of documents, teamwork, and productivity discussion meetings. In addition, the authors used other techniques typical of the scientific field such as: the process approach, process maps, the Information Organizational Scheme, feasibility studies, the Process Assurance Model, the Balanced Scorecard (BSC), the Gantt Chart and the Deming Cycle.

The main results achieved were: the contents of the management model for support services in the biotechnology sector and the procedure for its implementation.

\section{Theoretical bases of the model}

In the literature review, the authors analyzed two variants: the models focused on services and the models based on management.

For the first variant, 13 service models were analyzed, including the molecular model [16-18], the Servuction Model [19, 20], the $8 \mathrm{P}$ model [21, 22], the JetBlue airline model [23], the management model of the Basque government's electronic services Vasco-V005 [24], the service model unifying the beverage support services of Beam Spain [25], the AT\&T model [26], the Iberia model [27], the business model Canvas [28, 29], the Johnson \& Johnson service model [30], and the Copa airline model [31].

Other review service models were those [32-35] [Girardo Otálora 2012; Ynzenga, 2012; Estrada, 2017; Napolitano, 2018) of the largest companies in the world in 2016, whose stock market value was over 100 billion euros. However, their models are not applicable to this type of research.

The main service models differ from each other in terms of their application: the Servuction Model applies to any service and creates a positive experience for the customer, offering a package of benefits to the consumer. The molecular model has a limited application as customers never get to know a service process as they get to know products; and managers do not develop a broader vision of their products, so they will not be able to better understand customers' needs and the way in which they can be satisfied.

The $8 \mathrm{P}$ model also has a limited application and it is most suitable to position a product or service in the market. The rest of the service models analyzed are based on the basic models and are applied according to the sector, the corporate purpose and the needs of companies. The authors consider that there are three fundamental service models that provide the basis for the other models. These models were compared as to their definition, components, factors, service experience and application.

The model to be used will be chosen according to the type of service. However, the Servuction Model is applicable to any service, and the authors believe that it is possible to organize support services on the basis of this model.

In the second phase of research, management models were investigated. These consist of a generic scheme or frame of reference for the administration of an entity; they must be centered on processes, people and technology and aligned with the mission, vision and values of the organization in order to achieve the proposed objectives [36]. Management models include the Deming Cycle for continuous improvement $[37,38]$, the Balanced Scorecard $[39,40]$, the result pyramid [41], the EFQM model [42], the Effective Progress and Performance Measurement [43], the SERVQUAL [44], ISO 9001/2015 [45], and ISO 20000-1: 2018 on the requirements of IT service management systems [46].

Additionally, the Process Assurance Model (MAP, by its Spanish acronym) created by Acevedo [47] under the same conditions of application of this study was also examined. This model focuses on how to guarantee processes with a systemic approach.

The models analyzed share characteristics such as the strategic approach, the form of diagnosis, the process approach and the continuous improvement of processes based on the feedback obtained from the analysis of results. These elements were taken into account for the model design proposed in this research. The analysis of these models formed the theoretical basis for the MOGESA (Management Model of Support Services in Biotechnology Companies).

That is why the MOGESA is based on the integration of service and management models $[48,49]$. The service part of the model consists of the Servuction Model $[19,20]$, while the management part is based on the combination of three pillars: the Process Assurance Model (MAP), which is a logistics model that allows differentiating the contents of management at the strategic, tactical and operational levels [47, 50-53]; the Deming Cycle (PHVA) for continuous improvement $[37,38,54]$ and the Balanced Scorecard (BSC) to exercise management control $[39,40,55,56]$. 


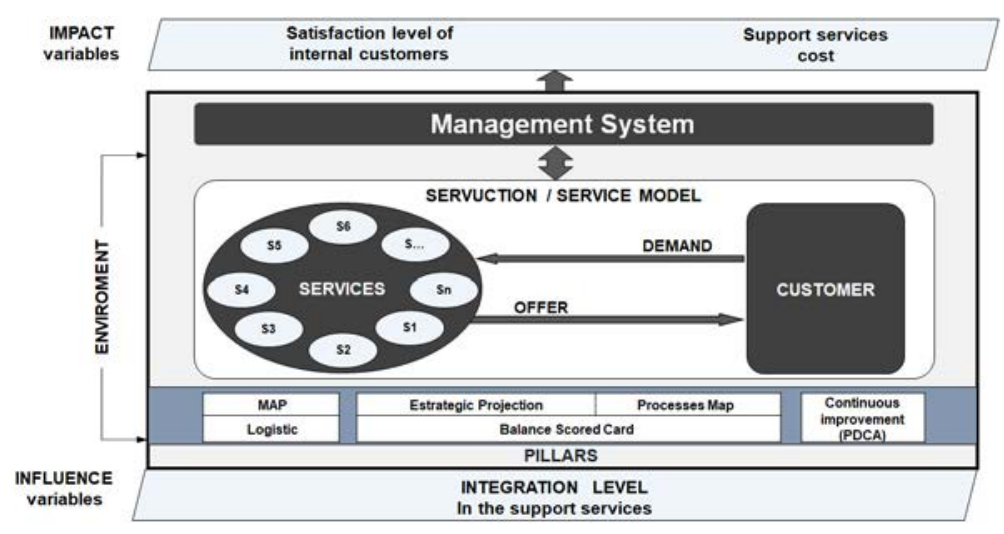

Figure 1 Model for the management of support services in a biotechnology company

Table 1 Definition of the model's premises, characteristics, objectives and relations with the environment

\begin{tabular}{|c|c|}
\hline \multicolumn{2}{|c|}{ Management Model of Support Services in a Biotechnology company } \\
\hline Premises & Characteristics \\
\hline $\begin{array}{l}\text { Commitment and interest of the middle } \\
\text { and senior management involved in } \\
\text { processes and support services }\end{array}$ & $\begin{array}{l}\text { Customer satisfaction: the specific attributes for each } \\
\text { type of service are taken into account. }\end{array}$ \\
\hline $\begin{array}{l}\text { Specialists' basic knowledge of } \\
\text { management and service models }\end{array}$ & $\begin{array}{l}\text { Flexibility: the model and the relevant procedures can } \\
\text { be applied according to the specific conditions of any } \\
\text { company that includes support services in its corporate } \\
\text { purpose or secondary objectives. }\end{array}$ \\
\hline $\begin{array}{l}\text { Application of a logistic model based on } \\
\text { the MAP }\end{array}$ & $\begin{array}{l}\text { A high degree of integration: decision-making is the } \\
\text { result of a general analysis aimed at achieving optimal } \\
\text { performance in accordance with the objectives of the } \\
\text { model irrespective of particular interests. }\end{array}$ \\
\hline $\begin{array}{l}\text { Motivation and involvement of the } \\
\text { contact personnel, based on the } \\
\text { recognition of the importance of their } \\
\text { work }\end{array}$ & $\begin{array}{l}\text { Continuous improvement: it allows systematic feedback } \\
\text { by managing processes to raise the level of customer } \\
\text { satisfaction. }\end{array}$ \\
\hline $\begin{array}{l}\text { Compliance of managers, specialists and } \\
\text { contact personnel with the competencies } \\
\text { required by their position }[57,58]\end{array}$ & Efficiency: measured through the cost of services. \\
\hline \multicolumn{2}{|r|}{ Objectives } \\
\hline \multicolumn{2}{|c|}{ To organize a service model based on the concept of Servuction that favors customer satisfaction. } \\
\hline \multicolumn{2}{|c|}{$\begin{array}{l}\text { To apply the contents of this model to each element of the MAP: objectives, inputs, activities and } \\
\text { outputs to be included in the logistic system of support services. }\end{array}$} \\
\hline \multicolumn{2}{|c|}{$\begin{array}{l}\text { To define and implement a system of indicators to exercise management control as proposed by the } \\
\text { model }\end{array}$} \\
\hline \multicolumn{2}{|c|}{$\begin{array}{l}\text { To carry out a diagnosis of the organization, to proactively search for improvement opportunities in } \\
\text { the service and process areas of the company. }\end{array}$} \\
\hline \multicolumn{2}{|c|}{ MOGESA's relations with the environment } \\
\hline Influence variables & Impact variables \\
\hline \multirow{2}{*}{$\begin{array}{l}\text { The level of integration of support } \\
\text { services or the level of integration in the } \\
\text { integration nodes of supply chains [4] } \\
\text { allows determining, through a survey, the } \\
\text { structuring of } 4 \text { modules with integration } \\
\text { elements. }\end{array}$} & $\begin{array}{l}\text { The level of satisfaction of internal customers make } \\
\text { it possible to measure whether the service offered by the } \\
\text { organization meets or exceeds customer expectations. } \\
\text { This indicator provides information on the behavior of } \\
\text { services and is assessed through satisfaction surveys. }\end{array}$ \\
\hline & $\begin{array}{l}\text { The cost of services (CS) refers to the capacity of the } \\
\text { organization to generate expenses and raise the level of } \\
\text { customer satisfaction. } C S=\sigma G \text {, where G: Service } \\
\text { charges }\end{array}$ \\
\hline
\end{tabular}




\section{Methodology}

This paper focuses on the development of a model favoring the management of support services and the procedure for its implementation in the Cuban context. It also takes account of the demands of the political, economic, social and environmental situation. The conventional support services provided in biotechnology companies; the variables that are directly impacted (level of customer satisfaction and cost of services); and the influence variables (level of integration of support services) that are within the scope of the organization and can determine the success or failure of the model's application and its inputs (customer demand) and outputs (service supply).

The contents of the MOGESA are shown in Figure 1. The relationship between the pillars of the models lies in the fact that each component of the Servuction Model is managed through the corresponding elements of the MAP's management cycles (strategic, tactical and operational). The results of the management system are reflected in the perspectives of the BSC. For example: if the contact personnel component is adopted, it will require the assurance of the personnel and knowledge elements. The management results are reflected in the indicators of the growth and learning perspective. The characterization of the MOGESA covers the premises, characteristics, objectives and relations with the environment to be considered by the model, as shown in Table 1. The structure of the service model based on Servuction is described as made up of: components, definition, contents and results.

With regard to the relations of the management model with the environment, it must be clarified that the environment of the organization consists of a set of areas or subsystems that is related to the organization itself and does not necessarily coincide with its management structure, since the projection of the system is independent of its organizational structure. However, in order to facilitate the identification of the environment, the authors have assigned codes to its component parts, which are similar to the terminology used in Cuban companies.

The information that the management model exchanges with the environment can be coded as follows:

1. When the information goes from the environment towards the model.

$X X \cdot Y Y$

$X X=$ Code of the environment area or subsystem where the information originates

$Y Y=$ Consecutive number of information

2. When the information goes from the model towards the environment.

IS $\bullet Y Y$

IS= Code indicating that the information comes from the management model

$Y Y=$ Consecutive number of information

The management model is made up of the MAP and the BSC, as shown in Table 4. The MAP, which is a logistic model, is a novel aspect of this research. The Supplier-Inputs-Process-Outputs-Customer (SIPOC) diagram shows the sequential set of main functions involved in the fulfillment of a given activity or management process, as well as the internal and external interrelations; therefore, this is a graph that accurately reflects the content of any given activity or subsystem. The SIPOC diagram can be used as a tool to balance the flow of information as all the information received comes from a specific function of another system [59].

The authors developed the SIPOCs associated with the MAP, specifically for each element of the MAP and management cycles. The objectives and responsible parties were described, in addition to inputs and their sources, activities, outputs and destinations.

\section{Results}

This section intends to demonstrate the results of the application of the MOGESA at the CIM from 2012 to 2018.

Stage I: Analysis and diagnosis

Step 1: Characterization of the organization

Within the CIM, the model was applied to conventional service processes in the SERVICIM Division, which is in charge of efficiently providing these services (food, transportation, logistics, energy, construction maintenance, general services, physical protection and economyl to the scientific, productive and commercial departments of the CIM and their workers.

The Vision of the organization: Becoming a leader in the provision of high-quality and fast services to CIM.

The characterization took into account: the corporate purpose of the organization and other activities complementary to the CIM's fundamental activity; the annual work targets during the specified period; the structure of the Servuction Model, which is at the heart of the MOGESA's service model; the application of the process map reflecting the BSC's supplier-client relationships, processes and services, procedures and indicators. 
The inputs provided by the management model are detailed to obtain the corresponding outputs, through a scheme of input and output information relations. The environment areas surrounding the management model are also presented, as well as the code and the description of the meaning of the information used in order to simplify its identification. The application of the MAP to SERVICIM is shown in Figure 2. The authors developed the organizational and informational schemes (EOIs) of each element of the MAP for the strategic, tactical and operational cycles of the logistic management model.

Taking into consideration that objectives vary annually from step 1 to step 7, a yearly analysis was carried out to achieve continuous improvement; for step 3, after the BSC analysis, the procedure for the transport service was further developed, introducing improvements in every management cycle.

A diagnosis of the services was carried out, using surveys to measure customer satisfaction, interviews with department directors and direct observation.

Surveys were applied to workers who represent between $30 \%$ and $44 \%$ of the total number of employees at the center; then, the sample was validated and the results obtained were processed according to the satisfaction surveys. Step 2: Analysis of services

The application of the procedure from step 2 shows that there is still a significant level of dissatisfaction among customers, mainly in relation to food, transport and logistic services.

It also highlights that the problems related to food and transport reappear from time to time, and the quality of these services exhibits both high and low indicators.

Nevertheless, the historical analysis of opinion surveys reveals that the number of people satisfied with the services provided has increased, even when external limitations persist and continue to be barriers to the achievement of a better service.

In the past years, the annual report meetings of SERVICIM have allowed the detection of insufficiencies or the non-fulfillment of work objectives and these results were linked to the contents of the MAP, in order to identify logistic management problems.

Step 3: Analysis of the behavior of indicators

All processes have their own working procedures and indicators that measure their level of activity on the basis of the BSC.

The BSC of SERVICIM shows the relations between the activities carried out and the way in which processes and services are monitored throughout the specified period, including food, transport and logistic services as mentioned in their diagnosis.

Although it is not possible for all services to work under the same integrated management system, in some cases, the BSC automatically draws from the general data obtained from the management system of each service.

These indicators are reviewed every year and analyzed monthly in management meetings and measures are taken in case of any abnormality, that is to say, the cause and effect of the indicators obtained are analyzed to improve the performance of the organization.

It was confirmed that the problems detected are reflected in the process and customer-related indicators. The customer satisfaction indicator is above the target value and the level of integration coincides with the target value, which indicates that the measures applied have had a positive effect.

Then, the procedure to be applied in the transport service was further developed and its main indicators are presented in Table 2.

This table shows the rise of the process and customer indicators; however, one of the problems detected is dissatisfaction with some personnel transport routes due to the increase in the number of people that take those routes.

\section{Stage II: Changes or measures}

At this stage, the Chief of Transportation, the Transportation Operation Specialists and Technicians, bus drivers and Heads of Workshops play an important role.

Steps 4 and 5: Introduction of measures and implementation schedule. On the basis of the results of the previous stage, a series of new measures were introduced in the transport service and implemented annually, as shown in Table 3. Stage III: Implementation and control

Steps 6 and 7: Implementation of improvement, control and monitoring measures and their impact variables (performance indicators). The monitoring and feedback on the tasks of the improvement project for the transport service are executed monthly at SERVICIM management meetings. After obtaining the demand-capacity balance 


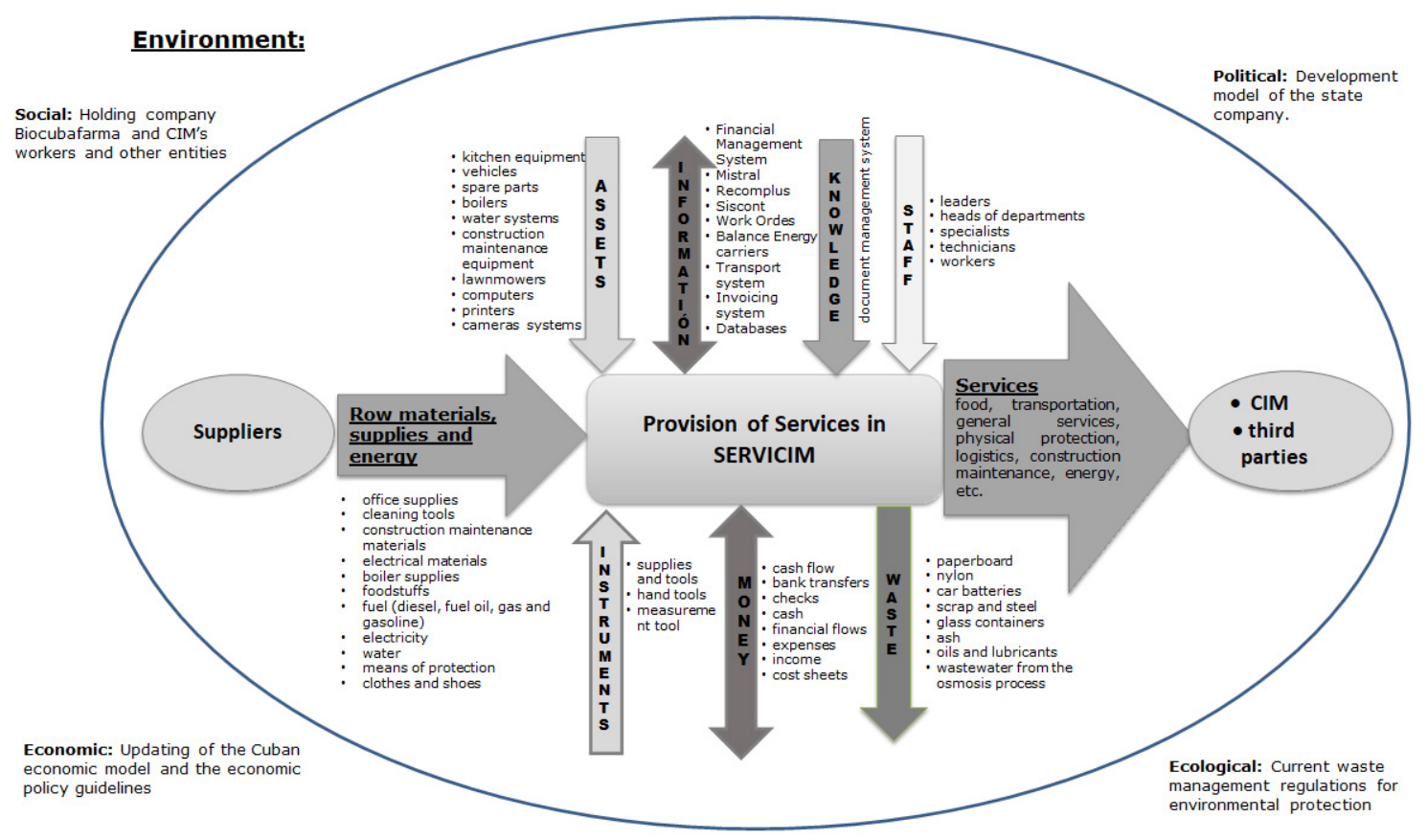

Figure 2 Specific content of the elements of the MAP of SERVICIM

Table 2 Management indicators of the Transport Service

\begin{tabular}{clcccccc}
\hline No. & Indicators & Target value & $\mathbf{2 0 1 2}$ & $\mathbf{2 0 1 4}$ & $\mathbf{2 0 1 6}$ & Target value & $\mathbf{2 0 1 8}$ \\
\hline 1 & \% Orders closed & 100 & 86.1 & 89.1 & 90.6 & 100 & 93.3 \\
\hline 2 & \% Customer Satisfaction in Transportation & $85-90$ & 79 & 89 & 93 & $85-90$ & 97 \\
\hline 3 & Transport efficiency index $(\mathrm{Km} / 1)$ & 4.0 & 4.6 & 4.3 & 4.4 & 5.6 & 5.8 \\
\hline 4 & \% Technical availability coefficient & $\geq 85$ & 82.7 & 85.0 & 90.0 & $\geq 85$ & 90.0 \\
\hline 5 & \% Execution of the maintenance plan & 100 & 91.7 & 91.4 & 93.2 & 100 & 94.7 \\
\hline
\end{tabular}

and studying the transport routes in March 2012, it was concluded that it is necessary to contract a feasibility study. The transportation improvement project was planned for a 2-year period, but it actually took 7 years, for the following reasons: delay in the discussion and approval of the feasibility study by the organizations involved; the execution of the bus delivery schedule in two installments, as not all the buses demanded were allocated in the same year; the delayed purchase and arrival of imported vehicles and delays in the process of technical discontinuance of vehicles due to their replacement and the registration of new vehicles. The rest of the measures mentioned below were implemented within the established timeframe, and proved to be effective for the development of the transport process: introduction of the transport management system, implementation of the transport base service, application of surveys to assess the level of customer satisfaction, installation of magnetic fuel conditioners, improvement of work orders, implementation of a new transport management system, approval and implementation of the transport base project, restructuring of the automotive workshop and implementation of a new route using route plotting.

Through the adoption of organizational and investment measures, the transport process indicators began showing a favorable behavior, which reveals an improvement in the performance of this service, aimed at achieving greater customer satisfaction.

Other improvements implemented in the rest of the services were: the development and improvement of management systems, including the generation of work orders (energy, steam and construction maintenance), invoicing and generation of service requests; food planning and logistics management; studies for the reorganization of logistic services and general food, construction maintenance, energy and transportation services, la study was conducted on the optimal use of the working day, the distribution of functions per service and the improvement of working conditions); recoding and classification of 
Table 3 Introduction of measures in the transport service

\begin{tabular}{|c|c|}
\hline No. & Introduction of measures in the transport service \\
\hline 1 & $\begin{array}{l}\text { Personnel transport routes were reorganized according to the actual concentration of personnel per } \\
\text { municipality and the availability of passenger transport. }\end{array}$ \\
\hline 2 & The demand for mass transportation was studied according to the daily route system. \\
\hline 3 & $\begin{array}{l}\text { The behavior of the occupancy levels of the existent mass transport capacity was studied for all routes and } \\
\text { pick-up points, revealing the over-exploitation of buses with a passenger overload of } 60 \% \text {. }\end{array}$ \\
\hline 4 & Transport consumption rates were controlled and analyzed per driver. \\
\hline 5 & A feasibility study proposing the purchase and replacement of equipment was prepared. \\
\hline 6 & A demand-capacity balance was issued as part of the feasibility study. \\
\hline 7 & $\begin{array}{l}\text { A transport management system was implemented to handle the requests of the various areas received from the } \\
\text { information system, which favors a better planning of the service focused on the client and its evaluation } \\
\text { The system is a working tool for the obtainment of statistical information and the analysis of the transport service. }\end{array}$ \\
\hline 8 & $\begin{array}{l}\text { The implementation of the feasibility study was completed, with the increase of the number of vehicles to } 28 \\
\text { and the replacement of some of them. }\end{array}$ \\
\hline 9 & $\begin{array}{l}\text { The transport base was restructured, covering the service in all downtown areas and personnel mass transport } \\
\text { routes. Before } 2016 \text {, there were } 7 \text { buses with } 448 \text { routes covering } 13944 \mathrm{~km} \text { annually; as of } 2016 \text {, the number } \\
\text { was increased to } 12 \text { buses for a total of } 19 \text { with } 672 \text { routes covering } 23384 \mathrm{~km} \text { per year. }\end{array}$ \\
\hline 10 & Biannual surveys were conducted to evaluate the quality of each type of service. \\
\hline 11 & Magnetic fuel conditioners were installed in every vehicle to improve fuel efficiency. \\
\hline 12 & $\begin{array}{l}\text { A new transport management system was implemented (drafting of reports according to the needs, based on } \\
\text { resolution 382/2013 and 383/2013 of the Ministry of Transport [60]) }\end{array}$ \\
\hline 13 & Work orders were improved. \\
\hline 14 & The transport base project was approved and implemented. \\
\hline 15 & $\begin{array}{l}\text { The automotive workshop was restructured: delimitation of the workshop area for vehicle access and } \\
\text { installation of lockers on the fence for the storage of mechanic tools. }\end{array}$ \\
\hline 16 & $\begin{array}{l}\text { A new route was implemented using route plotting: a route that departed from Santiago de las Vegas and } \\
\text { entered Fontanar was divided into } 2 \text { routes: one leaving from Santiago de las Vegas and the other from } \\
\text { Fontanar }\end{array}$ \\
\hline
\end{tabular}

Table 4 Integration of the service packages with the processes and elements of the MAP

\begin{tabular}{|c|c|c|c|c|}
\hline No. & Service packages & Integration Relation & Relation between processes & MAP elements \\
\hline 1 & Food & $\begin{array}{l}\text { Table plan (computer system) } \\
\text {-provision of the breakfast, } \\
\text { lunch, dinner and snacks } \\
\text { service- monthly payroll } \\
\text { discount }\end{array}$ & $\begin{array}{c}\text { Food-Logistics } \\
\text { Other processes: } \\
\text { Informatics-Human } \\
\text { Development-Economy }\end{array}$ & $\begin{array}{l}\text { Information-personnel-raw } \\
\text { materials and materials- } \\
\text { assets-instruments-money- } \\
\text { service }\end{array}$ \\
\hline 2 & Mass transport & $\begin{array}{l}\text { Route plans-monthly payroll } \\
\text { discount }\end{array}$ & $\begin{array}{l}\text { Transport-Logistics } \\
\text { Other processes: } \\
\text { Informatics-Human } \\
\text { Development-Economy }\end{array}$ & $\begin{array}{c}\text { Information-personnel-raw } \\
\text { materials and materials- } \\
\text { assets-payroll-money- } \\
\text { service }\end{array}$ \\
\hline
\end{tabular}

supplies in warehouses; replacement of conventional luminaires with LED technology and installation of a water treatment plant to recover the water used in the osmosis production process.

In order to raise the level of customer satisfaction, service packages were designed, revealing the level of integration of SERVICIM processes achieved through the management system; Table 4 shows the integration of service packages with the processes and elements of the MAP.

\section{Conclusions}

The development of the MOGESA and its procedure to be applied in support services constitute the solution to the problem of this research, providing an answer to the problems identified in SERVICIM. Also, this model reveals the interaction of service activities with the scientific research, production and commercialization activities to help increase the efficiency of companies.

The design of the MOGESA covers premises, characteristics, objectives, relations with the environment, the service model components, and the elements and 
functions of the management model, in order to ensure continuous improvement and thus raise the level of customer satisfaction with the logistic system.

The general procedure proposed for the application of the MOGESA constitutes a working tool for the application of the management model in the strategic, tactical and operational cycles of a biotechnology company's services.

The novelty of this research lies in the development and application of the MOGESA to conventional services in a biotechnology company under the conditions of the Cuban context, strengthened by the MAP logistic model, which encompasses all management cycles and elements.

The management of support services in the biotechnology sector by using the MOGESA has made it possible to increase the level of customer satisfaction and reduce the cost of support services.

\section{Declaration of competing interest}

The authors declare that they have no significant competing interests, including financial or non-financial, professional or personal interests that may interfere with the complete and objective presentation of the work described in this manuscript.

\section{Acknowledgments}

The authors thank the Molecular Immunology Center for its support in the conduct of this research and the Technological University of Havana for its innovative knowledge.

\section{Funding}

This work was supported by the Molecular Immunology Center of Havana

\section{Author contributions}

Daime Padilla, José Antonio Acevedo and Ana Julia Urquiaga are the creators of the model, as part of the former's doctoral thesis. For their part, Ana Julia Acevedo and Neyfe Sablón contributed to the methodological support and application of the model, together with its creators.

\section{Data availability statement}

The data that supports the application of the model was obtained from several degree projects and practices of the students; as well as during the more than 10 years of work of Daimee Padilla at the Molecular Immunology Center. These data are the property of the Molecular Immunology Center and are available in its internal databases and in the University's Library.

\section{References}

[1] M. Amaro-Rosales and D. Villavicencio-Carbajal, "Incentivos a la innovación de la biotecnología agrícola-alimentaria en México," Estudios Sociales, vol. 23, no. 45, 2015. [Online]. Available: http://www.scielo.org.mx/scielo.php?script= sci_arttext\&pid=S0188-45572015000100002

[2] M. Espinosa, E. Ojito, A. Lage, and M. Delgado, “El Centro de Inmunología Molecular: crecimiento y desafíos de la empresa de alta tecnología en el contexto cubano de desarrollo socialista," Cofin Habana, vol. 12, no. 2, Feb. 20, 2018. [Online]. Available: http://scielo.sld.cu/scielo.php?script=sci_arttext\&pid= S2073-60612018000200007

[3] J. Acevedo and M. Gómez, “Estado de la logística y el desarrollo de las redes de valor en empresas cubanas en perfeccionamiento empresarial," in XIII LOGMARK Nacional Las Tunas. Las Tunas: LOGICUBA, 2010.

[4] Y. Pardillo-Baez and M. Gómez-Acosta, "Modelo de diseño de nodos de integración en las cadenas de suministro," Ingeniería Industrial, vol. 34, no. 1, 2013. [Online]. Available: https://bit.ly/3o8ym6d

[5] T. López, "Modelo y procedimiento para el desarrollo de la gestión integrada de cadenas de suministro en cuba," Undergraduate thesis, Ingeniería Industrial, Facultad de Ingeniería Industrial, Instituto Superior Politécnico José Antonio Echeverría, La Habana, Cuba, 2014.

[6] Y. L. León, F. Marrero, M. Pérez, and J. González, “Identificación de restricciones físicas en el sistema logístico de empresas comercializadoras en Holguín, Cuba," Visión de Futuro. Revista científica, vol. 21, no. 1, 2017. [Online]. Available: https://bit.ly/ 3rsGL6K

[7] A. Acevedo, N. Sablón, J. Acevedo, M. Gómez, and T. López, "Formación logística en Cuba: desafíos y perspectivas," Revista Universidad y Sociedad, vol. 11, no. 1, Mar. 2, 2019. [Online]. Available: http://scielo.sld.cu/scielo.php?script=sci_arttext\&pid= S2218-36202019000100172

[8] A. Vallín, "Mejora de la logística de importaciones del centro de inmunología molecular," Undergraduate thesis, Dirección y Gestión Empresarial, Escuela Superior de Cuadros del Estado y del Gobierno, La Habana, Cuba, 2104.

[9] M. Espinosa-Valdés, A. Lage-Dávila, and M. Delgado-Fernández, "Evolución de la gestión organizacional en un centro cubano de la biotecnología," Ingeniería Industrial, vol. 38, no. 3, May. 24, 2017. [Online]. Available: https://bit.ly/3d7wJQ7

[10] F. Domínguez-Pérez, I. Lopes-Martínez, P. Felipe-Valdés, A. Vallin-García, and A. Cruz-Ruiz, "Propuesta de clasificación de insumos para la gestión de inventarios en la industria biofarmacéutica. Caso de Estudio en el Centro de Inmunología Molecular," Vaccimonitor, vol. 27, no. 2, May. 2018. [Online]. Available: https://bit.ly/3xQwSRL

[11] L. Quiala-Tamayo and et al., "Una nueva visión en la gestión de la logística de aprovisionamientos en la industria biotecnológica cubana," Vaccimonitor, vol. 27, no. 3, Sep. 2108. [Online]. Available: http://scielo.sld.cu/scielo.php?script=sci_arttext\&pid= S1025-028X2018000300003

[12] D. Padilla, “Sistema de gestión para la unidad empresarial base de 
administración y servicios del centro de inmunología molecular," M.S. thesis, Facultad de Ingeniería Industrial, Instituto Superior Politécnico José Antonio Echeverría, La Habana, Cuba, 2003.

[13] D. Padilla-Aguiar, J. Acevedo-Suárez, A. Lage-Dávila, and F. Figaredo-Curiel, "El cuadro de mando integral en el centro de inmunología molecular," Ingeniería Industrial, vol. 35, no. 2, Jul. 15, 2014. [Online]. Available: http://scielo.sld.cu/scielo.php?script= sci_arttext\&pid=S1815-59362014000200011

[14] D. Padilla, Y. Pardillo, and J. Acevedo, "Análisis de los servicios del CIM," Paper presented at the 17 Convención Científica de Ingeniería y Arquitectura en la VI Conferencia Internacional del CELALE del 24 al 28 de noviembre del 2014, La Habana, Cuba, 2014.

[15] S. Auh, B. Menguc, P. Imer, and A. Uslu, "Frontline employee feedback-seeking behavior: How is it formed and when does it matter?" Journal of Service Research, vol. 22, no. 1, 2019. [Online]. Available: https://doi.org/10.1177/1094670518779462

[16] G. L. Shostack, "Breaking Free from Product Marketing," Journal of Marketing, vol. 41, no. 2, Apr. 1977. [Online]. Available: https: //doi.org/10.2307/1250637

[17] O. Furrer, D. Sudharshan, R. Tsiotsou, and B. Li, "A framework for innovative service design," The Service Industries Journal, vol. 36, no. 9-10, Nov. 7, 2016. [Online]. Available: https: //doi.org/10.1080/02642069.2016.1248420

[18] D. S. Siu, M. A. Guerrero, and K. Solì-s, "La servucción y su importancia en los modelos de negocios actuales," INNOVA Research Journal, vol. 2, no. 8, Aug. 2017. [Online]. Available: https://doi.org/10.33890/innova.v2.n8.2017.241

[19] P. Eiglier and E. Langeard, Servuction. Le marketing des services. Ediscience International, 1996.

[20] D. Hoffman and J. Bateson, Services Marketing: Concepts, Strategies, \& Cases. Boston: Cengage Learning, 2016.

[21] J. W. Hood, "A conceptual instrument to measure the success of branding in the tourism industry," PhD thesis, North-West University, South Africa, 2015.

[22] J. Wirtz, C. Lovelock, and P. Chew, Essentials of Services Marketing, 3rd ed. Pearson, 2017.

[23] B. Dodds, "JetBlue Airways: Service Quality As A Competitive Advantage," Journal of Business Case Studies, vol. 3, no. 4, Oct. 1, 2007. [Online]. Available: https://doi.org/10.19030/jbcs.v3i4.4863

[24] Gobierno Vasco. (2011) Modelo de gestión de los servicios electrónicos del gobierno vasco-v005. [Online]. Available: https: //bit.ly/3piREW3

[25] C. Beam. (2014) Beam. gestión de aplicaciones: unificando el servicio de soporte e implementando un nuevo modelo de servicio. Ciber Inc. [Online]. Available: www.ciber.es

[26] J. Power. (2017, Feb. 16,) At\&t sweeps all categories to take the top ranking in j.d. power purchase experience full-service study. Accessed May. 29, 2018. [Online]. Available: https://bit.ly/3EYIXAe

[27] L. Gallego. (2015) International airlines group logrando juntos. estados financieros consolidados condensados para el ejercicio finalizado a 31 de diciembre de 2015. IBERIA. [Online]. Available: https://bit.ly/35QdwSi

[28] A. Osterwalder and Y. Pigneur, Business model generation : a handbook for visionaries, game changers, and challengers. Wiley, 2013.

[29] J. Ojasalo and K. Ojasalo, "Service logic business model canvas," Journal of Research in Marketing and Entrepreneurship, vol. 20, no. 1, Mar. 26, 2018. [Online]. Available: https://www.emerald.com/ insight/content/doi/10.1108/JRME-06-2016-0015/full/html

[30] (2017) Puestos de trabajo en servicios generales. Johnson \& Johnson Services. [Online]. Available: http://www-careers-jnj-com. jnjnab25.jnj.com/es/facilities

[31] Copa Airlines . (2016, Mar.) Código de ética y conducta empresarial. [Online]. Available: https://bit.ly/3qtavOC

[32] C. Giraldo, "Propuesta de mejora al proceso de servicio al cliente para el área de químicos de la empresa químicofarmacéutica merck s.a de colombia," Undergraduate thesis, Ingenieria Industrial, Pontificia Universidad Javeriana, Bogotá, 2012.

[33] F. Ynzenga, "Pfizer: mercado global integrado," Logística integral: la cadena de suministro sin fronteras, no. 87, 2012. [Online]. Available: https://dialnet.unirioja.es/servlet/articulo? codigo $=4019265$

[34] Roche America Latina. (2017) Informe de sostenibilidad 2016-2017. [Online]. Available: https://bit.ly/3mDlHag

[35] G. Napolitano and J. S. (trans.), Motivation in the workplace: A procter and gamble case study. Babelcube Inc, 2018.

[36] D. P. Aguiar, J. A. A. Suárez, and A. J. U. Rodríguez, "Modelo de gestión de los servicios de apoyo en empresa de la biotecnología," PhD. thesis, Disertación doctoral no publicada, Universidad Tecnológica de La Habana, La Habana, Cuba, 2019.

[37] W. E. Deming, Out of the Crisis. Cambridge, USA: MIT press, 2018.

[38] N. M. Agrawal, “Modeling deming's quality principles to improve performance using interpretive structural modeling and micmac analysis," International Journal of Quality \& Reliability Management, vol. 36, no. 7, Agu. 5, 2019. [Online]. Available: https://doi.org/10. 1108/IJQRM-07-2018-0204

[39] R. Kaplan and P. Norton, El cuadro de mando integral: The balanced scorecard, 3rd ed. Barcelona, Spain: Grupo Planeta Spain, 2014.

[40] A. Agarwal, "Investigating design targets for effective performance management system: an application of balance scorecard using qfd," Journal of Advances in Management Research, vol. 18, no. 3, Sep. 17, 2020. [Online]. Available: https://doi.org/10.1108/ JAMR-05-2020-0075

[41] C. J. McNair, R. L. Lynch, and K. F. Cross, "Do financial and nonfinancial performance measures have to agree?" Strategic Finance, vol. 72, no. 5, Nov. 1990. [Online]. Available: https://www.proquest.com/docview/ 229739909 ?pq - origsite $=$ gscholar\&fromopenview=true

[42] A. M. Din, M. Asif, M. U. Awan, and G. Thomas, "What makes excellence models excellent: a comparison of the american, european and japanese models," The TQM Journal, vol. 33, no. 6, Nov. 18, 2020. [Online]. Available: https://doi.org/10.1108/ TQM-06-2020-0124

[43] C. Adams and P. Roberts, You are what you measure. Manufacturing Europe. London: Sterling Publications, 1993.

[44] S. Altuntas and S. Kansu, "An innovative and integrated approach based on servqual, qfd and fmea for service quality improvement: A case study," Kybernetes, vol. 49, no. 10, Dec. 6, 2019. [Online]. Available: https://doi.org/10.1108/K-04-2019-0269

[45] ISO. (2015, Sep. 15,) Norma internacional iso 9001:2015. Ginebra, Suiza. [Online]. Available: http://www.congresoson.gob.mx:81/ Content/ISO/documentos/ISO_9001_2015.pdf

[46] ISO and IEC. (2018, Sep.) Iso/iec 20000-1 - information technology -service management - part 1: Service management system requirements. [Online]. Available: https://fliphtml5.com/thlf/gmce/ basic

[47] J. A. Acevedo, "Modelos y estrategias de desarrollo de la logística y las redes de valor en el entorno de cuba y latinoamérica," PhD. thesis, Facultad de Ingeniería Industrial, Instituto Superior Politécnico José Antonio Echeverría, La Habana, Cuba, 2008.

[48] D. P. Aguiar, J. A. A. Suárez, and A. J. U. Rodriguez, Modelo de gestión de los servicios de apoyo en empresa de la biotecnología. La Habana, Cuba: CELALE, 2016.

[49] D. P. Aguiar and J. A. Acevedo Suárez and A. J. Urquiaga Rodriguez, "Modelo de gestión de los servicios de apoyo en empresa de la biotecnología paper presented at the idifarma 2018," IV Congreso Internacional de Investigación-Desarrollo e Innovación Tecnológica en la Industria Biofarmacéutica del 3 al 7 de Diciembre del 2018, La Habana, Cuba, 2018.

[50] Y. S. Lima, Análisis de los problemas y buenas prácticas de las empresas cubanas actuales. La Habana, Cuba: CUJAE, 2013.

[51] A. Torralbas and L. E. S. Marful, "Análisis de la cadena logística de la producción de anticuerpos monoclonales en la planta de antyter," Undergraduate thesis, Facultad de Ingeniería Industrial, Instituto Superior Politécnico José A. Echeverria, La Habana, Cuba, 2014.

[52] A. R. Morales, "Aplicación del modelo de aseguramiento al proceso (map) en la producción de ampolletas en la ueb aica," M.S. thesis, Tesis de maestría no publicada, Instituto Superior Politécnico José A. Echeverria, La Habana, Cuba, 2016.

[53] L. A. D. L. Torre, D. P. Aguiar, and M. C. Casas, "Sistema de 
gestión logístico en servicim para la toma de decisiones," in 19 Convención Científica de Ingeniería y Arquitectura en el X Taller de Gestión Empresarial (GE) del 26 al 30 de noviembre del 2018., La Habana. Cuba, 2018.

[54] H. J. Harrington and J. S. Harrington, Administración total del mejoramiento continuo : la nueva generación. Santafé de Bogotá Mcgraw-Hill, 1997.

[55] O. Nils-Göran, J. Roy, and M. Wetter, Implantando Y Gestionando El Cuadrode Mando Integral. Gestio 2000, 2000.

[56] R. S. Kaplan and D. P. Norton, The execution premium: Integrando la estrategia y las operaciones para lograr ventajas competitivas. Barcelona, España: Grupo Planeta Spain, 2014.

[57] N. M. Bénitez, "La influencia del sistema de gestión integrado de capital humano como tecnología organizativa en la práctica tecno científica de las áreas de producción bajo regímenes de trabajo irregulares del centro de inmunología molecular," Tecnología, Sociedad e Innovación, vol. 112, 2013.

[58] Y. C. Díaz, “Tecnología para la gestión estratégica del capital humano en empresas de alta tecnología del sector biotecnológico farmacéutico," PhD. thesis, Departamento de Ingeniería Industrial. Facultad de Ingeniería Industrial, Universidad Tecnológica de La Habana José Antonio Echeverría, La Habana, Cuba, 2017.

[59] A. Benešová, M. Hirman, F. Steiner, and J. Tupa, "Determination of changes in process management within industry 4.0," Procedia Manufacturing, vol. 38, 2019. [Online]. Available: https://doi.org/10. 1016/j.promfg.2020.01.112

[60] (2013, Apr. 24,) Resolución n 383/13 - normas sobre el reporte de combustible habilitado y kilómetros recorridos. Cuba. [Online]. Available: http://extwprlegs1.fao.org/docs/pdf/cub126978.pdf 